\title{
Examination of the Link Between Medication Adherence and Use of Mail-Order Pharmacies in Chronic Disease States
}

\author{
Elena V. Fernandez, BS; Jennifer A. McDaniel, MSLS; and Norman V. Carroll, PhD
}

\begin{abstract}
BACKGROUND: Higher medication adherence is associated with positive health outcomes, including reduction in hospitalizations and costs, and many interventions have been implemented to increase patient adherence.

OBJECTIVES: To determine whether patients experience higher medication adherence by using mail-order or retail pharmacies.

METHODS: Articles pertaining to retail and mail-order pharmacies and medication adherence were collected from 3 literature databases: MEDLINE, Cumulative Index to Nursing and Allied Health Literature (CINAHL), and International Pharmaceutical Abstracts (IPA). Searches were created for each database and articles were compiled. Articles were screened for exclusion factors, and final articles $(n=15)$ comparing medication adherence in patients utilizing mail and retail pharmacies were analyzed. For each study, various factors were identified including days supply, patients' out-of-pocket costs, prior adherence behavior, therapeutic class, measure of adherence, limitations, and results. Studies were then categorized by disease state, and relevant information from each study was compared and contrasted.
\end{abstract}

RESULTS: The majority of studies-14 out of the 15 reviewed-supported higher adherence through the mail-order dispensing channel rather than through retail pharmacies. There are a number of reasons for the differences in adherence between the channels. Study patients who used mail-order pharmacies were more likely to have substantially higher prior adherence behavior, socioeconomic status, and days supply of medicines received and were likely to be offered financial incentives to use mail-order. The few studies that attempted to statistically control for these factors also found that patients using mail-order services were more adherent but the size of the differences was smaller. The extent to which these results indicate an inherent adherence advantage of mail-order pharmacy (as distinct from adherence benefits due to greater days supply, lower copays, or more adherent patients selecting mail-order pharmacies) depends on how well the statistical controls adjusted for the substantial differences between the mail and retail samples.

CONCLUSIONS: While the research strongly indicates that consumers who use mail-order pharmacies are more likely to be adherent, more research is needed before it can be conclusively determined that use of mail-order pharmacies causes higher adherence.

J Manag Care Spec Pharm. 2016;22(11):1247-59

Copyright $\odot 2016$, Academy of Managed Care Pharmacy. All rights reserved.

\section{What is already known about this subject}

Patient nonadherence to prescribed medications is high across the population and has been shown to decrease desired health outcomes and increase hospitalizations and medical costs.

There have been many attempts to increase adherence, and several studies have compared patient adherence across dispensing channels.

\section{What this study adds}

In this review, most studies found higher medication adherence in patients who used mail-order pharmacies.

Patients who used mail-order pharmacies were more likely to have higher prior adherence behavior, socioeconomic status, and days supply of medicines received and were more likely to be offered financial incentives to use mail order than patients using retail pharmacies.

The few studies that statistically controlled for prior adherence behavior, days supply of medicines, socioeconomic factors, and financial incentives also found that patients using mail-order pharmacies were more adherent, but the size of the differences was smaller.

1 atient nonadherence to prescribed medications has been shown to decrease desired health outcomes and increase hospitalizations and medical costs. ${ }^{1,2}$ Medication adherence for treatment of chronic diseases is still poor across the population, with reports of less than $50 \%$ of patients taking their medications as prescribed. ${ }^{3-7}$ High medication costs, beliefs that medications are not necessary, transportation access, and unfavorable side effects are among the reasons that patients are not adherent to their medications. It is in the best interest of the health care community to determine ways to increase patient adherence in order to improve health outcomes and decrease hospital admissions and costs. There have been many attempts to increase adherence. Conn et al. (2015) summarized interventions to increase medication adherence, including introduction of medication therapy management (MTM) by educating patients on proper drug administration through provider counseling. ${ }^{8}$ Other attempts to increase adherence include (a) encouraging patients to self-manage, (b) use of medication calendars/diaries/pill boxes/drug reminders, (c) motivational interviewing to identify and correct barriers 
Examination of the Link Between Medication Adherence and Use of Mail-Order Pharmacies in Chronic Disease States

\begin{tabular}{|c|c|c|}
\hline$\#$ & Search & Results \\
\hline 1 & ("Medication Adherence"[Mesh]) OR (("adherence" OR "compliance" OR "medication adherence")) & 145,744 \\
\hline 2 & ("Postal Service"[Mesh]) OR (("postal service" OR "mail" OR " mail service")) & 62,099 \\
\hline 3 & $\begin{array}{l}\text { ((“Pharmacy"[Mesh] OR "Pharmacies"[Mesh] OR "Pharmacy Service, Hospital”[Mesh] OR "Community Pharmacy Services”[Mesh] OR } \\
\text { "Pharmaceutical Services, Online”[Mesh] OR "Pharmaceutical Services”[Mesh] OR "Insurance, Pharmaceutical Services”[Mesh]))) OR } \\
\text { (("community pharmacy" OR "retail pharmacy" OR "pharmacy services")) }\end{array}$ & 44,528 \\
\hline 4 & $\begin{array}{l}\text { ((((("Pharmacy"[Mesh] OR "Pharmacies"[Mesh] OR "Pharmacy Service, Hospital”[Mesh] OR "Community Pharmacy Services”[Mesh] OR } \\
\text { "Pharmaceutical Services, Online”[Mesh] OR "Pharmaceutical Services"[Mesh] OR "Insurance, Pharmaceutical Services”[Mesh]))) OR } \\
\text { ((“community pharmacy" OR "retail pharmacy" OR "pharmacy services")))) AND ((“Medication Adherence”[Mesh]) OR (("adherence" OR } \\
\text { "compliance" OR "medication adherence"))) }\end{array}$ & 3,933 \\
\hline 5 & 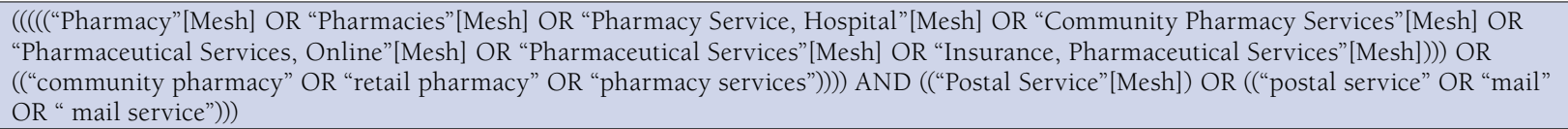 & 762 \\
\hline 6 & 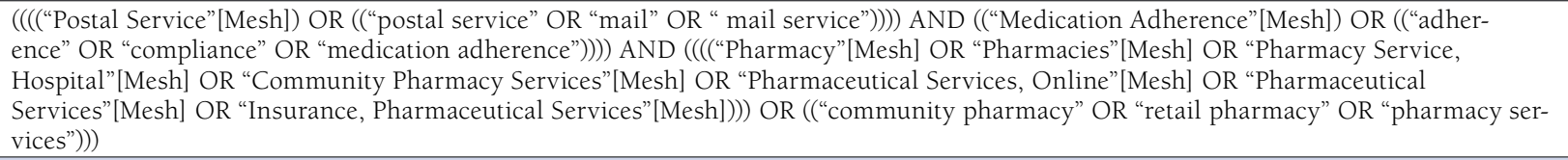 & 86 \\
\hline 7 & 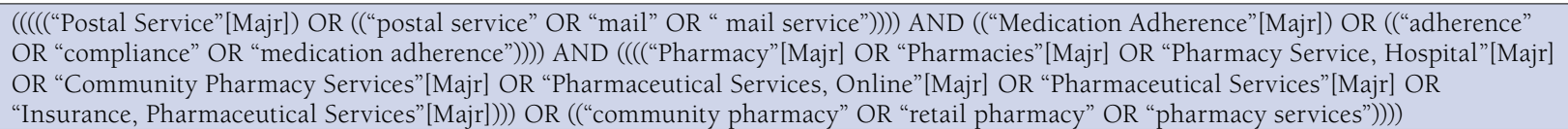 & 64 \\
\hline
\end{tabular}

Note: MEDLINE was searched for various Medical Subject Headings (MeSH) and keywords pertaining to medication adherence and mail-order pharmacies as of June 29, 2015. The search was limited to English language and human subjects only.

and behavior by goal setting, (d) increasing communication with providers and social support, and (e) rewards including financial incentives for patients by doctors, insurance companies, and pharmacy benefit managers (PBMs). ${ }^{8-10}$ Aside from altering patient behaviors or incentives, several studies have compared patient adherence across dispensing channels.

Patients usually have the option to fill prescriptions through retail or mail-order pharmacies. Mail-order pharmacies provide patients with a number of advantages that could lead to greater adherence. Filling prescriptions through a mail-order pharmacy provides patients greater convenience by cutting out trips to retail pharmacies. This is especially advantageous for patients who have physical problems or lack of transportation that limits their ability to travel to pharmacies. Mail-order pharmacies also provide greater convenience by providing 90-day supplies of medications, rather than the 30-day supplies that are more commonly dispensed from retail pharmacies. Having medicines on hand and ease of refilling may both contribute to higher adherence. ${ }^{11}$ Insurance companies and PBMs often provide financial incentives that make filling prescriptions via mail-order pharmacies less expensive for patients. ${ }^{12-14}$ Greater affordability may lead to greater adherence. Finally, mail-order may provide greater privacy in that the prescription is not filled in the community where the patient lives or is not picked up in a public place. This may be an important factor for patients on medicines for conditions that have social stigma. An advantage of retail is face-to-face interaction with a pharmacist. This may increase adherence through clarification of prescriptions and more in-depth counseling on use of drugs for which patients may be less adherent. ${ }^{15,16}$ For example, Ratanawongsa et al. (2013) showed that increased communication and education about diabetic medications led to higher adherence. ${ }^{17}$ Additionally, Bauer et al. (2013) showed that patients with health literacy limitations had poorer adherence than those without such limitations. ${ }^{18}$

The primary goal of this systematic review was to identify whether patient adherence is related to dispensing channel. A second goal was to determine whether differences in adherence between channels were a result of inherent differences between the channels or the result of confounding factors such as days supply, financial incentives, or patient differences.

\section{Methods}

\section{Literature Search}

Literature searches were conducted in MEDLINE, Cumulative Index to Nursing and Allied Health Literature (CINAHL), and International Pharmaceutical Abstracts (IPA) databases. Initially, a broad search strategy of relevant keywords was used to find evidence of patient medication adherence in retail and mail-order pharmacies. Search terms in the broad search included medication adherence and mail and retail pharmacy. Searches were built for each database to obtain all possible relevant articles.

Relevant subject headings for each of the 3 databases were determined and searches were constructed based on subject headings and key terms (Table 1 shows search results for MEDLINE). 


\section{FIGURE 1 Flow Diagram of Article Selection}

Databases: MEDLINE, CINAHL, and IPA

Limits: English-language articles and human subjects only, $\mathrm{N}=124$

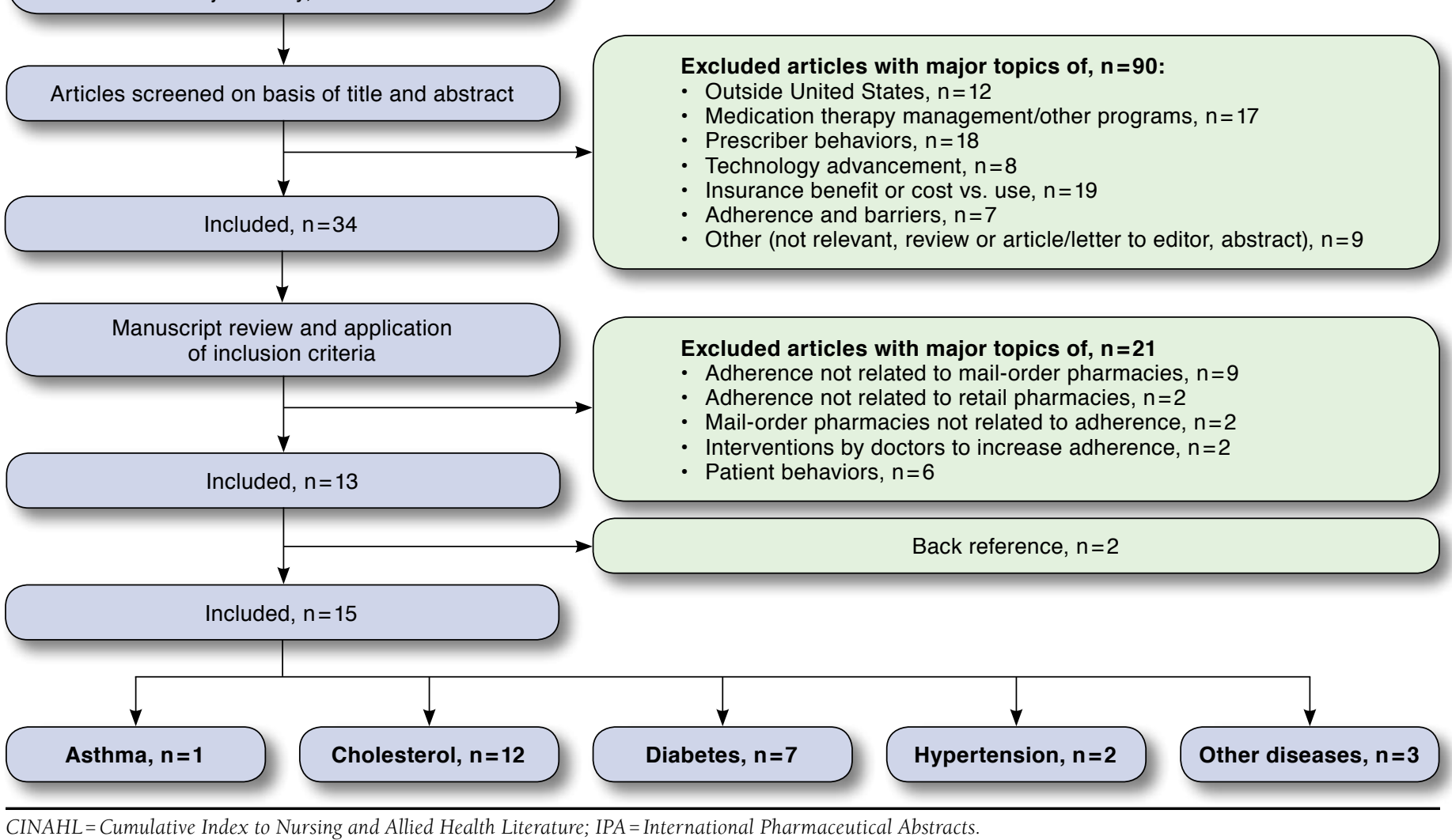

Search results from MEDLINE, CINAHL, and IPA produced 124 articles after duplications where removed (Figure 1).

Following the PRISMA guidelines for reporting systematic reviews, 124 articles were screened by title and abstract for primary exclusion criteria. ${ }^{19}$ These included studies conducted outside of the United States; studies that examined adherence to medication after introduction of MTM or other programs to improve adherence, prescribing behaviors and adherence, technology advancement and adherence, insurance benefit or cost and drug utilization, and barriers to medication adherence; and review articles and letters to the editor or articles that did not examine medication adherence in mail and retail settings. Primary exclusion resulted in a total of 34 articles that were further analyzed.

The remaining articles were reviewed in depth for secondary exclusion criteria, which included articles mentioning mailorder pharmacies or adherence individually but not together, articles about interventions by prescribers to increase patient adherence, and articles examining patients' internal motivations to be adherent. This resulted in a sample of 13 articles. Two additional articles were found as a result of reviewing the references in these articles. This resulted in a final total of 15 articles that examined the relationship between dispensing channel and medication adherence.

\section{Data Extraction and Interpretation}

For purposes of this review, articles were categorized by chronic disease. Articles were reviewed for factors that could account for differences in adherence across dispensing channels and relevant information was pre-determined, extracted, and summarized (Table 2). These factors included measures of adherence, days supply, out-of-pocket (OOP) costs, prior adherence behavior (PAB), and automatic prescription refills (auto-refill). As mentioned earlier, higher days supply and lower OOP costs may increase adherence, and mail and retail pharmacies frequently differ on these variables. PAB, measured as adherence in the prestudy period, 


\section{TABLE 2 Summary of Articles Comparing Adherence at Mail and Retail Pharmacies}

\begin{tabular}{|c|c|c|c|c|c|c|c|c|}
\hline $\begin{array}{l}\text { First Author } \\
\text { and Reference }\end{array}$ & $\begin{array}{l}\text { Ages in } \\
\text { Sample } \\
\text { (Years) }\end{array}$ & $\begin{array}{l}\text { How Mail-Order Users } \\
\text { Were Identified }\end{array}$ & $\begin{array}{l}\text { New or } \\
\text { Established } \\
\text { Users in } \\
\text { Sample } \\
\end{array}$ & $\begin{array}{c}\text { Sample } \\
\text { Size }\end{array}$ & $\begin{array}{l}\text { Source of } \\
\text { Sample }\end{array}$ & $\begin{array}{l}\text { Adherence } \\
\text { Measure }\end{array}$ & Drug Classes & $\begin{array}{l}\text { Major Baseline Differences } \\
\text { in Mail and Retail Samples }\end{array}$ \\
\hline Visaria 20 & $12-63$ & $\begin{array}{l}\text { The index medication } \\
\text { claim was dispensed at } \\
\text { a mail pharmacy or the } \\
\text { days supply was }>84 \text { days }\end{array}$ & New & 6,000 & MSCCE & MPR & Antiasthmatics & No major differences \\
\hline Khandelwal $^{15}$ & $\begin{array}{l}\text { Mean }= \\
65.2 \text { for } \\
\text { retail } \\
61.4 \text { for } \\
\text { mail }\end{array}$ & $\begin{array}{l}\text { Patients who used mail } \\
\text { (retail) for all prescrip- } \\
\text { tions in the therapeutic } \\
\text { class were classified as } \\
\text { mail (retail) patients. } \\
\text { Patients using both } \\
\text { channels were excluded }\end{array}$ & Established & 54,000 & $\begin{array}{c}\text { PBM } \\
\text { database }\end{array}$ & MPR & $\begin{array}{l}\text { Antiasthmatics/ } \\
\text { bronchodilator agents, } \\
\text { antidepressants, } \\
\text { antidiabetics, } \\
\text { antihypertensives, beta } \\
\text { blockers, diuretics, and } \\
\text { thyroid agents } \\
\end{array}$ & No major differences \\
\hline Pittman $^{21}$ & $18-63$ & $\begin{array}{l}\text { Use of mail-order for } \\
>80 \% \text { of antihyperten- } \\
\text { sive medications }\end{array}$ & Both & 625,000 & $\begin{array}{l}\text { Commercial } \\
\text { insurance }\end{array}$ & MPR & Antihypertensives & $\begin{array}{l}\text { Baseline characteristics for } \\
\text { mail vs. retail patients were } \\
\text { not reported }\end{array}$ \\
\hline Adams $^{22}$ & $18+$ & $\begin{array}{l}\text { "voluntary enrollment in } \\
\text { a mail-order program." } \\
\text { This included having at } \\
\text { least the first fill of the } \\
\text { prescription from a } \\
\text { mail-order pharmacy }\end{array}$ & New & 44,000 & KPNC & CMG & Antihypertensives & $\begin{array}{l}\text { Baseline characteristics for } \\
\text { mail vs. retail patients were } \\
\text { not reported }\end{array}$ \\
\hline lyengar $^{23}$ & $18-64$ & $\begin{array}{l}\text { At least } 66.7 \% \text { of pre- } \\
\text { scriptions from mail- } \\
\text { order pharmacy; also } \\
\text { had a mixed-channel } \\
\text { group for patients with } \\
<66.7 \% \text { of prescrip- } \\
\text { tions through mail and } \\
<66.7 \% \text { of prescriptions } \\
\text { through retail }\end{array}$ & Both & 4,000 & $\begin{array}{l}\text { Commercial } \\
\text { insurance } \\
\text { members } \\
\text { from a PBM }\end{array}$ & MPR & $\begin{array}{l}\text { Antidiabetics, } \\
\text { antihypertensives, } \\
\text { antihyperlipidemics }\end{array}$ & $\begin{array}{l}18-21 \text { percentage points } \\
\text { more mail patients were } \\
\text { adherent in the baseline } \\
\text { period }\end{array}$ \\
\hline Iyengar 24 & $65+$ & $\begin{array}{l}\text { At least } 66.7 \% \text { of pre- } \\
\text { scriptions from mail- } \\
\text { order pharmacy; also } \\
\text { had a mixed-channel } \\
\text { group for patients with } \\
<66.7 \% \text { of prescrip- } \\
\text { tions through mail and } \\
<66.7 \% \text { of prescriptions } \\
\text { through retail }\end{array}$ & Both & 800,000 & $\begin{array}{l}\text { Medicare } \\
\text { Part D claims } \\
\text { from a PBM } \\
\text { database }\end{array}$ & PDC & $\begin{array}{l}\text { Antidiabetics, } \\
\text { antihypertensives, } \\
\text { antihyperlipidemics }\end{array}$ & $\begin{array}{l}14-16 \text { percentage points } \\
\text { more mail patients were } \\
\text { adherent in the baseline } \\
\text { period; } 17-25 \text { percentage } \\
\text { points more retail patients } \\
\text { received LIS; mean OOP } \\
\text { payments were } \$ 3-\$ 5 \text { higher } \\
\text { for retail patients }\end{array}$ \\
\hline White 25 & $18-75$ & $\begin{array}{l}\text { Mail-order patients were } \\
\text { those who used mail } \\
\text { pharmacies exclusively, } \\
\text { and retail patients were } \\
\text { those who used retail } \\
\text { pharmacies exclusively. } \\
\text { Patients using both } \\
\text { types were excluded }\end{array}$ & New & 15,000 & $\begin{array}{l}\text { Commercial } \\
\text { and Medicare } \\
\text { members of a } \\
\text { large HMO }\end{array}$ & $\begin{array}{c}\text { MPR, } \\
\text { persistence }\end{array}$ & $\begin{array}{l}\text { HMG reductase } \\
\text { inhibitors }\end{array}$ & $\begin{array}{l}87 \% \text { of mail patients were } \\
\text { covered by Medicare vs. } 56 \% \\
\text { of retail patients }\end{array}$ \\
\hline Schmittdiel26 & $18-80+$ & $\begin{array}{l}\text { Patients who used mail } \\
\text { order "at least once" }\end{array}$ & New & 100,000 & KPNC & LDL-C levels & Statins & $\begin{array}{l}67.2 \% \text { of mail patients vs. } \\
45.3 \% \text { of retail patients were } \\
\text { non-Latino Caucasians; } \\
30.4 \% \text { of mail patients vs. } \\
18.3 \% \text { of retail patients had } \\
\text { financial incentives to } \\
\text { use mail order } \\
\end{array}$ \\
\hline Duru $^{27}$ & $\begin{array}{l}>17 \\
\text { years }\end{array}$ & $\begin{array}{l}\text { Patients with }>66 \% \text { of } \\
\text { refills by mail were classi- } \\
\text { fied as mail patients, and } \\
\text { those with } 100 \% \text { of refills } \\
\text { at retail were classified as } \\
\text { retail patients. Patients } \\
\text { with } 1 \%-66 \% \text { of refills at } \\
\text { mail were excluded }\end{array}$ & Both & 14,000 & KPNC & CMG & $\begin{array}{l}\text { Antilipids, } \\
\text { antihypertensives, } \\
\text { antiglycemics }\end{array}$ & $\begin{array}{l}61 \% \text { of mail patients vs. } 37.1 \% \\
\text { of retail patients were non- } \\
\text { Latino whites, } 27.5 \% \text { of mail } \\
\text { patients vs. } 17.8 \% \text { of retail } \\
\text { patients were in the least } \\
\text { deprived SES quartile, and } \\
49.6 \% \text { of mail users vs. } 23.0 \% \\
\text { of retail users had a financial } \\
\text { incentive to use mail }\end{array}$ \\
\hline
\end{tabular}




\section{TABLE 2 Summary of Articles Comparing Adherence at Mail and Retail Pharmacies (continued)}

\begin{tabular}{|c|c|c|c|c|c|c|c|c|}
\hline $\begin{array}{l}\text { First Author } \\
\text { and Reference }\end{array}$ & $\begin{array}{l}\text { Ages in } \\
\text { Sample } \\
\text { (Years) }\end{array}$ & $\begin{array}{l}\text { How Mail-Order Users } \\
\text { Were Identified }\end{array}$ & $\begin{array}{l}\text { New or } \\
\text { Established } \\
\text { Users in } \\
\text { Sample }\end{array}$ & $\begin{array}{c}\text { Sample } \\
\text { Size }\end{array}$ & $\begin{array}{l}\text { Source of } \\
\text { Sample }\end{array}$ & $\begin{array}{l}\text { Adherence } \\
\text { Measure }\end{array}$ & Drug Classes & $\begin{array}{l}\text { Major Baseline Differences } \\
\text { in Mail and Retail Samples }\end{array}$ \\
\hline Gibson $^{28}$ & $18+$ & $\begin{array}{l}\text { Patients with "any mail- } \\
\text { order use in the past } \\
\text { year" were classified as } \\
\text { mail patients }\end{array}$ & Both & 97,000 & $\begin{array}{l}\text { Commercial } \\
\text { insurance }\end{array}$ & PDC & $\begin{array}{l}\text { Oral antidiabetics } \\
\text { and insulin }\end{array}$ & $\begin{array}{l}\text { Baseline characteristics for } \\
\text { mail vs. retail patients were } \\
\text { not reported }\end{array}$ \\
\hline Devine $^{29}$ & $18-64$ & $\begin{array}{l}\text { Mail-order users were } \\
\text { those who switched to } \\
\text { mail after an initial retail } \\
\text { fill of the medication; } \\
\text { patients could have 2 } \\
\text { retail fills after the switch } \\
\text { to mail and still be con- } \\
\text { sidered mail patients }\end{array}$ & Both & 58,000 & MSCCE & MPR & Oral antidiabetics & $\begin{array}{l}\text { No major } \\
\text { differences }\end{array}$ \\
\hline Zhang 30 & $\begin{array}{l}\text { Mean }= \\
72.3\end{array}$ & $\begin{array}{l}\text { Patients who used mail } \\
\text { (retail) for all prescrip- } \\
\text { tions in the therapeutic } \\
\text { class were classified as } \\
\text { mail (retail) patients. } \\
\text { Patients using both } \\
\text { channels were excluded }\end{array}$ & New & 23,000 & $\begin{array}{l}\text { Medicare } \\
\text { Part D claims } \\
\text { from PBM } \\
\text { database }\end{array}$ & PDC & Oral antidiabetics & $\begin{array}{l}\text { 30.7\% of mail patients vs. } \\
21.7 \% \text { of retail patients were } \\
\text { in MAPD plans; } 95.3 \% \text { of mail } \\
\text { patients vs. } 87.8 \% \text { of retail } \\
\text { patients were over } 64 \text { years of } \\
\text { age; mail patients were on a } \\
\text { mean of } 3 \text { distinct medication } \\
\text { vs. } 2.5 \text { for retail patients }\end{array}$ \\
\hline Sharma 31 & $18-64$ & $\begin{array}{l}\text { Individuals were } \\
\text { assigned to the phar- } \\
\text { macy where they had } \\
\text { a majority of their pre- } \\
\text { scriptions filled. The } \\
\text { database did not identify } \\
\text { pharmacies as mail or } \\
\text { retail; researchers clas- } \\
\text { sified pharmacies filling } \\
>50 \% \text { of prescriptions } \\
\text { in the sample through } \\
\text { mail as mail pharmacies } \\
\text { and those filling }>50 \% \\
\text { at retail as retail } \\
\text { pharmacies }\end{array}$ & Both & 408,000 & $\begin{array}{l}\text { Employer- } \\
\text { sponsored } \\
\text { private } \\
\text { health plans }\end{array}$ & PDC & $\begin{array}{l}\text { Antidiabetics, } \\
\text { including injectable } \\
\text { insulin }\end{array}$ & $\begin{array}{l}\text { Baseline characteristics for } \\
\text { mail vs. retail patients were } \\
\text { not reported }\end{array}$ \\
\hline Curkendall $^{32}$ & $\begin{array}{l}\geq 18 \\
\text { years }\end{array}$ & $\begin{array}{l}\text { "The index drug was } \\
\text { characterized as to } \\
\text { whether it was a mail- } \\
\text { order prescription" }\end{array}$ & Established & 53,000 & MSCCE & $\begin{array}{c}\text { PDC, } \\
\text { persistence }\end{array}$ & $\begin{array}{l}\text { Noninsulin } \\
\text { antidiabetics }\end{array}$ & $\begin{array}{l}\text { Baseline characteristics for } \\
\text { mail vs. retail patients were } \\
\text { not reported }\end{array}$ \\
\hline Kirkman 33 & $20-75+$ & $\begin{array}{l}\text { Patients who filled any } \\
\text { of their diabetes medica- } \\
\text { tions by mail were con- } \\
\text { sidered mail patients }\end{array}$ & Both & 218,000 & \begin{tabular}{|l|} 
PBM \\
covering pre- \\
dominantly \\
commercial \\
members \\
\end{tabular} & MPR & $\begin{array}{l}\text { Noninsulin } \\
\text { antidiabetics }\end{array}$ & $\begin{array}{l}\text { Baseline characteristics for } \\
\text { mail vs. retail patients were } \\
\text { not reported }\end{array}$ \\
\hline
\end{tabular}

continued on next page

was included to control for selection bias that would occur if patients who were more adherent were also more likely to use one of the channels. Both retail and mail-order pharmacies may offer patients the choice of having their prescriptions auto-refilled. Auto-refill prescriptions are automatically refilled and shipped to the patient so that there should never be gaps in the patient's drug therapy. Auto-refill prescriptions may artificially inflate adherence measures that are based on claims data. Other factors that were extracted included patient demographics, source of sample, and sponsor information.

\section{Results}

In this section, the relevant methods and results are briefly presented for each study. Studies are grouped by chronic disease, and a number of the studies examined more than 1 disease. Relevant information from each study is summarized in Table 2 .

\section{Asthma}

Two studies examined medication adherence and the use of mail-order or retail pharmacies for patients with asthma. In a retrospective analysis, Visaria et al. (2012) measured 


\section{TABLE 2 Summary of Articles Comparing Adherence at Mail and Retail Pharmacies (continued)}

Part 2: Statistical Controls, Results, and Sponsors

\begin{tabular}{|c|c|c|c|c|c|c|c|}
\hline $\begin{array}{l}\text { First Author } \\
\text { and Reference }\end{array}$ & $\begin{array}{l}\text { Controlled for } \\
\text { OOP Costs }\end{array}$ & $\begin{array}{c}\text { Controlled } \\
\text { for PAB }\end{array}$ & $\begin{array}{l}\text { Controlled for } \\
\text { Days Supply }\end{array}$ & $\begin{array}{c}\text { Controlled for } \\
\text { Disease Severity }\end{array}$ & Numeric Results & $\begin{array}{l}\text { Length of } \\
\text { Follow-Up } \\
\text { Period } \\
\text { (Months) }\end{array}$ & $\begin{array}{l}\text { Sponsor/ } \\
\text { Author } \\
\text { Affiliation }\end{array}$ \\
\hline Visaria $^{20}$ & $\begin{array}{l}\text { Total OOP } \\
\text { medical and } \\
\text { pharmacy costs } \\
\text { in the study year }\end{array}$ & No & No & $\begin{array}{l}\text { CCI; comorbidities known } \\
\text { to affect asthma severity or } \\
\text { asthma-related resource use; } \\
\text { ED, inpatient, and outpatient } \\
\text { visits; and SABA claims in the } \\
\text { baseline period }\end{array}$ & $\begin{array}{l}\text { Adjusted MPR was } 62.4 \% \\
\text { for mail vs. } 39.7 \% \text { for retail; } \\
23.1 \% \text { of mail vs. } 11.1 \% \text { of } \\
\text { retail patients had an MPR } \\
>80 \%\end{array}$ & 12 & $\begin{array}{l}\text { Express } \\
\text { Scripts }\end{array}$ \\
\hline Khandelwal15 & $\begin{array}{l}\text { Included only } \\
\text { mail and retail } \\
\text { patients with } \\
\text { equal copays } \\
\text { for } 90 \text {-day } \\
\text { prescriptions }\end{array}$ & No & $\begin{array}{l}\text { Only included } \\
\text { prescriptions } \\
\text { with } 90 \text {-day } \\
\text { supply }\end{array}$ & $\begin{array}{l}\text { Risk scores were developed } \\
\text { based on NDCs from pharmacy } \\
\text { claims }\end{array}$ & $\begin{array}{l}\text { MPRs were } 77.0 \% \text { for mail } \\
\text { vs. } 76.0 \% \text { for retail; no dif- } \\
\text { ferences within therapeutic } \\
\text { classes except in diabetes, } \\
\text { which favored mail }(83.1 \% \\
\text { vs. } 80.2 \% \text { ) }\end{array}$ & 12 & Walgreens \\
\hline Pittman $^{21}$ & Copayment & No & No & $\begin{array}{l}\text { CDS and presence of CAD, } \\
\text { DM, dyslipidemia, stroke, } \\
\text { CHF, depression, and ESRD }\end{array}$ & $\begin{array}{l}\text { Adjusted OR of } 2.24 \text { for } \\
\text { mail }\end{array}$ & 12 & $\begin{array}{l}\text { Authors } \\
\text { employed } \\
\text { by Medco }\end{array}$ \\
\hline Adams 22 & $\begin{array}{l}\text { Medication } \\
\text { copayment } \\
\text { category }\end{array}$ & No & Not reported & $\begin{array}{l}\text { HT medication used to initi- } \\
\text { ate therapy; most recent SBP } \\
\text { before initiating HT treatment; } \\
\text { diagnosis of CVD, CKD, DM, } \\
\text { schizophrenia, bipolar disorder, } \\
\text { anxiety, and depression; num- } \\
\text { ber of medical office visits dur- } \\
\text { ing the } 12 \text { months before start- } \\
\text { ing antihypertensive therapy }\end{array}$ & $\begin{array}{l}\text { Adjusted OR of } 0.57 \text { for } \\
\text { nonadherence at mail }\end{array}$ & 12 & $\begin{array}{l}\text { Federally } \\
\text { funded; } \\
\text { authors } \\
\text { employed } \\
\text { by KPNC }\end{array}$ \\
\hline Iyengar 23 & $\begin{array}{l}\text { OOP costs per } \\
\text { 30-day adjusted } \\
\text { prescription }\end{array}$ & \begin{tabular}{|l|} 
Patient \\
adherence \\
$(\geq 80 \%$ \\
MPR) in \\
the base- \\
line period \\
\end{tabular} & $\begin{array}{l}\text { Yes, also did } \\
\text { SA using only } \\
\text { patients receiving } \\
\text { 90-day supplies }\end{array}$ & $\begin{array}{l}\text { Number of therapy classes in } \\
\text { which the patient had a pre- } \\
\text { scription in baseline year }\end{array}$ & $\begin{array}{l}\text { Adjusted OR for mail was } \\
1.15 \text { for DM, } 1.11 \text { for HT, } \\
\text { and } 1.19 \text { for high } \\
\text { cholesterol }\end{array}$ & 12 & $\begin{array}{l}\text { Express } \\
\text { Scripts }\end{array}$ \\
\hline Iyengar ${ }^{24}$ & $\begin{array}{l}\text { OOP costs per } \\
\text { 30-day adjusted } \\
\text { prescription }\end{array}$ & $\begin{array}{l}\text { PDC in } \\
\text { baseline } \\
\text { year }\end{array}$ & $\begin{array}{l}\text { Yes, also did } \\
\text { SA using only } \\
\text { patients receiving } \\
\text { 90-day supplies }\end{array}$ & $\begin{array}{l}\text { Number of therapy classes in } \\
\text { which the patient had a pre- } \\
\text { scription in baseline year }\end{array}$ & $\begin{array}{l}\text { Adjusted OR for mail was } \\
1.25 \text { for DM,1.29 for HT, } \\
\text { and } 1.26 \\
\text { for high cholesterol }\end{array}$ & 12 & $\begin{array}{l}\text { Express } \\
\text { Scripts }\end{array}$ \\
\hline White 25 & No & No & No & CDS during the study period & $\begin{array}{l}\text { Adjusted MPR was } 92.6 \% \\
\text { for mail vs. } 82.5 \% \text { for retail; } \\
\text { persistence was } 278 \text { days for } \\
\text { mail vs. } 214 \text { for retail }\end{array}$ & 12 & $\begin{array}{l}\text { Prescription } \\
\text { Solutions }\end{array}$ \\
\hline Schmittdiel 26 & $\begin{array}{l}\text { IV was financial } \\
\text { incentive to } \\
\text { use mail order; } \\
\text { SA using only } \\
\text { patients receiving } \\
\text { no financial } \\
\text { incentives to use } \\
\text { mail order }\end{array}$ & $\begin{array}{l}\text { IV and } \\
\text { DID } \\
\text { analyses }\end{array}$ & $\begin{array}{l}\text { Most patients in } \\
\text { both mail and } \\
\text { retail samples } \\
\text { received } 100 \text {-day } \\
\text { supplies; results } \\
\text { indicated only } \\
\text { minor differ- } \\
\text { ences in days } \\
\text { supply between } \\
\text { mail and retail } \\
\text { patients }\end{array}$ & $\begin{array}{l}\text { Number of comorbidities, } \\
\text { presence of cardio-equivalent } \\
\text { conditions, use of antidepres- } \\
\text { sant medications, number of } \\
\text { primary care visits in baseline } \\
\text { period }\end{array}$ & $\begin{array}{l}85 \% \text { of mail vs. } 74.2 \% \text { of } \\
\text { retail achieved target LDL } \\
\text { levels }\end{array}$ & $3-15$ & KPNC \\
\hline Duru $^{27}$ & $\begin{array}{l}\text { Financial } \\
\text { incentive to use } \\
\text { mail order }\end{array}$ & $\begin{array}{l}\text { IV } \\
\text { analysis }\end{array}$ & $\begin{array}{l}\text { Most patients in } \\
\text { both mail and } \\
\text { retail samples } \\
\text { received } 100 \text {-day } \\
\text { supplies; results } \\
\text { indicated only } \\
\text { minor differ- } \\
\text { ences in days } \\
\text { supply between } \\
\text { mail and retail } \\
\text { patients }\end{array}$ & $\begin{array}{l}\text { Number of comorbidities, use } \\
\text { of antidepressant medications, } \\
\text { use of insulin }\end{array}$ & $\begin{array}{l}84.7 \% \text { of mail vs. } 76.9 \% \text { of } \\
\text { retail had good adherence } \\
\text { (defined as CMG }<20 \% \text { ); } \\
\text { mail vs. retail percentages } \\
\text { of good adherence were } \\
81.8 \% \text { vs. } 75.2 \% \text { for anti- } \\
\text { glycemics, } 88.1 \% \text { vs. } 80.4 \% \\
\text { for HT drugs, and } 81.7 \% \\
\text { vs. } 72.4 \% \text { for lipid- } \\
\text { lowering drugs }\end{array}$ & $12-15$ & KPNC \\
\hline
\end{tabular}


TABLE 2 Summary of Articles Comparing Adherence at Mail and Retail Pharmacies (continued)

\begin{tabular}{|c|c|c|c|c|c|c|c|}
\hline $\begin{array}{l}\text { First Author } \\
\text { and Reference }\end{array}$ & $\begin{array}{l}\text { Controlled for } \\
\text { OOP Costs }\end{array}$ & $\begin{array}{c}\text { Controlled } \\
\text { for PAB }\end{array}$ & $\begin{array}{l}\text { Controlled for } \\
\text { Days Supply }\end{array}$ & $\begin{array}{l}\text { Controlled for } \\
\text { Disease Severity }\end{array}$ & Numeric Results & $\begin{array}{l}\text { Length of } \\
\text { Follow-Up } \\
\text { Period } \\
\text { (Months) }\end{array}$ & $\begin{array}{l}\text { Sponsor/ } \\
\text { Author } \\
\text { Affiliation }\end{array}$ \\
\hline Gibson 28 & $\begin{array}{l}\text { "A cost-sharing } \\
\text { index created } \\
\text { for each } \\
\text { employer/plan } \\
\text { combination" }\end{array}$ & No & No & $\begin{array}{l}\text { CCI, visits to cardiologist or } \\
\text { endocrinologist in baseline } \\
\text { year }\end{array}$ & $\begin{array}{l}\text { Adjusted OR for mail was } \\
2.2 \text { for patients on oral } \\
\text { drugs only and } 2.3 \text { for } \\
\text { patients on oral drugs and/ } \\
\text { or insulin }\end{array}$ & 18 & $\begin{array}{l}\text { Thomson } \\
\text { Reuters }\end{array}$ \\
\hline Devine $^{29}$ & $\begin{array}{l}\text { OOP cost } \\
\text { for the index } \\
\text { antidiabetic } \\
\text { claim }\end{array}$ & $\begin{array}{l}\text { MPR } \\
\text { in the } \\
\text { baseline } \\
\text { period }\end{array}$ & No & $\begin{array}{l}\text { Depression diagnosis, CCI } \\
\text { score, antihypertensive use, } \\
\text { antidepressant use, modified } \\
\text { DCSI score }\end{array}$ & $\begin{array}{l}\text { Adjusted MPR was } 84.8 \% \\
\text { for mail vs. } 63.4 \% \text { for retail }\end{array}$ & $12-18$ & $\begin{array}{l}\text { Express } \\
\text { Scripts }\end{array}$ \\
\hline Zhang 30 & No & No & No & $\begin{array}{l}\text { CDS in baseline period, number } \\
\text { of distinct medications }\end{array}$ & $\begin{array}{l}\text { Adjusted PDC was } 68 \% \\
\text { for mail vs. } 61 \% \text { for retail; } \\
49.7 \% \text { of mail vs. } 42.8 \% \text { of } \\
\text { retail were adherent } \\
\text { (PDC } \geq 80 \% \text { ) }\end{array}$ & 12 & $\begin{array}{l}\text { Prescription } \\
\text { Solutions }\end{array}$ \\
\hline Sharma ${ }^{31}$ & Copay category & No & No & No & $\begin{array}{l}\text { PDC was } 8.6 \text { percentage } \\
\text { points higher for mail }\end{array}$ & 12 & $\begin{array}{l}\text { Wayne } \\
\text { State } \\
\text { University } \\
\text { School of } \\
\text { Pharmacy }\end{array}$ \\
\hline Curkendall $^{32}$ & $\begin{array}{l}\text { Average cost- } \\
\text { sharing amount } \\
\text { per } 30 \text {-day supply }\end{array}$ & No & No & $\begin{array}{l}\text { 3-digit ICD-9-CM diagnosis } \\
\text { codes and DCI in the pre- } \\
\text { period, visits to endocrinolo- } \\
\text { gists and cardiologists, presence } \\
\text { of renal impairment, macrovas- } \\
\text { cular disease or microvascular } \\
\text { disease in pre-period }\end{array}$ & $\begin{array}{l}\text { Adjusted OR for mail was } \\
1.60\end{array}$ & 12 & $\begin{array}{l}\text { Bristol- } \\
\text { Myers } \\
\text { Squibb }\end{array}$ \\
\hline Kirkman 33 & $\begin{array}{l}\text { OOP costs per } \\
30 \text {-day adjusted } \\
\text { prescription }\end{array}$ & No & No & $\begin{array}{l}\text { Pill burden for both diabetic } \\
\text { and nondiabetic medications; } \\
\text { whether patient was treated for } \\
\text { GI problems, high cholesterol, } \\
\text { HT, obesity, PVD, renal disease, } \\
\text { or depression }\end{array}$ & $\begin{array}{l}\text { Adjusted OR for mail was } \\
2.09\end{array}$ & 12 & $\begin{array}{l}\text { "Support for } \\
\text { the study } \\
\text { was pro- } \\
\text { vided to the } \\
\text { American } \\
\text { Diabetes } \\
\text { Association } \\
\text { by Amylin } \\
\text { Pharma- } \\
\text { ceuticals, } \\
\text { Novo } \\
\text { Nordisk, } \\
\text { and Sanofi" }\end{array}$ \\
\hline
\end{tabular}

$C A D=$ coronary artery disease; $C C I=$ Charlson Comorbidity Index; $C D S=$ chronic disease score; $C H F=$ congestive heart failure; $C M G=$ continuous measure of medication gaps; DCI = Deyo-Charlson Comorbidity Index; DCSI = Diabetes Complications and Severity Index; DID = difference in differences analysis; DM = diabetes mellitus; $E D=$ emergency department; $E S R D=$ end-stage renal disease; $G I=$ gastrointestinal; $H M O=$ health maintenance organization; HT =hypertension; ICD-9-CM = International Classification of Diseases, Ninth Revision, Clinical Modification; IV =instrumental variable; KPNC =Kaiser Permanente Northern California; LDL-C=low-density lipoprotein cholesterol; LIS =low-income subsidy; MAPD = Medicare Advantage Prescription Drug; MSCCE=MarketScan Commercial Claims and Encounters; MPR=medication possession ratio; $N D C=$ National Drug Code; $O O P=$ out-of-pocket; $O R=$ odds ratio; $P A B=$ prior adherence behavior; $P B M=$ pharmacy benefit manager; $P D C=$ proportion of days covered; $P V D=$ peripheral vascular disease; $S A=$ sensitivity analysis; $S A B A=$ short-acting beta antagonist; $S B P=$ systolic blood pressure; $S E S=$ socioeconomic status.

medication possession ratio (MPR) in commercially insured patients from 12 to 63 years old. This study concluded that adherence to medications to treat asthma was 22.73 percentage points higher in patients who utilized mail-order pharmacies (Table 3). The authors adjusted for various confounding factors, including patient age, gender, distance from a pharmacy, and total patient OOP drug expenditures by linear regression but did not account for days supply or PAB. ${ }^{20}$
In 2011, Khandelwal et al. examined the adherence of patients within a PBM taking medications for various conditions including asthma. ${ }^{15}$ MPR was determined for patients with prescriptions for 90-day supplies. Patients were propensity score-matched based on age, gender, and an average risk score calculated from a model developed by the University of California, San Diego, Chronic Illness and Disability Payment System, which predicts overall medical costs. The authors found no statistically significant differences in MPR pre- or 
TABLE 3 Comparison of MPRs and PDCs in Studies Comparing Mail and Retail Pharmacies.

\begin{tabular}{|c|c|c|c|c|}
\hline \multirow[b]{2}{*}{ Disease State } & \multirow[b]{2}{*}{ Group } & \multicolumn{3}{|c|}{ Differences } \\
\hline & & Mail-Order Group (\%) & Retail Group (\%) & Difference (\% points) \\
\hline \multirow[t]{2}{*}{ Asthma } & Visaria et al. ${ }^{20, a}$ & 62.4 & 39.7 & $22.7^{b}$ \\
\hline & Khandelwal et al. ${ }^{15, a}$ & 68.1 & 67.2 & 0.9 \\
\hline \multirow[t]{2}{*}{ Hypertension } & Khandelwal et al. ${ }^{15, a}$ & 79.0 & 79.0 & 0.0 \\
\hline & Duru et al. ${ }^{27, \mathrm{c}}$ & 88.1 & 80.4 & $7.7^{\mathrm{b}}$ \\
\hline \multirow[t]{3}{*}{ Cholesterol } & White et el. ${ }^{25, a}$ & 92.6 & 82.5 & $10.1^{\mathrm{b}}$ \\
\hline & Khandelwal et al. ${ }^{15, a}$ & 77.6 & 76.7 & 0.9 \\
\hline & Duru et al. ${ }^{27, \mathrm{c}}$ & 81.7 & 72.4 & $9.3^{b}$ \\
\hline \multirow[t]{5}{*}{ Diabetes } & Duru et al. ${ }^{27, \mathrm{c}}$ & 81.8 & 75.2 & $6.6^{b}$ \\
\hline & Devine et al. ${ }^{29, a, d}$ & 84.8 & 63.4 & $21.4^{b}$ \\
\hline & Zhang et al. $30, \mathrm{a}$ & 68.0 & 61.0 & $7.0^{\mathrm{b}}$ \\
\hline & Khandelwal et al. ${ }^{15, a}$ & 83.1 & 80.2 & 2.9 \\
\hline & Sharma et al. ${ }^{31, e}$ & Not reported & Not reported & 8.6 \\
\hline Depression & Khandelwal et al. ${ }^{15, a}$ & 72.3 & 71.5 & 0.8 \\
\hline CHF, CAD & Khandelwal et al. ${ }^{15, a}$ & 77.3 & 78.9 & 1.6 \\
\hline Thyroid & Khandelwal et al. ${ }^{15, a}$ & 80.2 & 80.8 & 0.6 \\
\hline \multicolumn{5}{|l|}{ Other diseases } \\
\hline Diuretics & Khandelwal et al. ${ }^{15, a}$ & 75.4 & 73.9 & 1.5 \\
\hline Calcium channel blockers & Khandelwal et al. ${ }^{15, a}$ & 78.9 & 79.3 & 0.4 \\
\hline \multicolumn{5}{|l|}{$\begin{array}{l}\text { Medication possession ratio. } \\
\text { bStatistically significant. } \\
{ }^{c} \text { Continuous measure of medica } \\
\text { dPatients switched groups. } \\
\text { eProportion of days covered. }\end{array}$} \\
\hline
\end{tabular}

postpropensity-matching between retail or mail-order use for 90-day prescriptions (Table 3). ${ }^{15}$ This study accounted for patient characteristics, patient OOP costs, and disease severity, but not for $\mathrm{PAB}$ or distance from a pharmacy.

\section{Hypertension}

In a 2010 study, Pittman et al. examined the relationship of adherence (MPR $\geq 80 \%$ ) to antihypertensive medication and health care use and costs in commercially insured patients. ${ }^{21}$ The authors included percentage of prescriptions filled through mail-order pharmacies as a control variable in a multivariable regression analysis. The results indicated that patients who received more than $80 \%$ of their prescriptions through mail had 2.24 times higher odds of being adherent (Table 4). The analysis controlled for patient OOP costs but not for days supply, $\mathrm{PAB}$, or distance from a pharmacy.

Adams et al. (2013) analyzed the relationship between race/ ethnicity, specific health system factors, early nonpersistence (failure to obtain the prescribed medication) and nonadherence (proportion of days covered $[\mathrm{PDC}]<80 \%$ ) to antihypertensive medications for new users enrolled in a large integrated health system. ${ }^{22}$ Mail-order usage was measured as "voluntary enrollment in a mail-order program" and appeared to indicate that the patient received at least the first fill of the antihypertensive prescription from a mail pharmacy. A multivariable logistic regression indicated that patients who used mail-order pharmacy had an odds ratio (OR) of 0.57 for nonadherence compared with nonusers of mail pharmacies (the OR of 0.57 for nonadherence is comparable to an OR of 1.75 for adherence) (Table 4). The analysis controlled for patient OOP costs but not for PAB or distance from a pharmacy. The article did not report whether days supply was controlled.

Iyengar et al. (2013) focused on various chronic conditions within a commercially insured population covered by a large PBM. In this study, where adherence was measured by MPR, hypertensive patients using mail-order pharmacies were more adherent than patients who used retail pharmacies after controlling, by multivariate logistic regression, for differences in age, gender, OOP cost, disease burden and severity, days supply and PAB. ${ }^{23}$ The authors calculated an adherence OR of 1.11 in mail versus retail pharmacies (Table 4).

A year later, in 2014, Iyengar et al. examined adherence among Medicare Part D beneficiaries. Within the hypertensive therapy class, patients receiving home delivery of medications (Iyengar's term for mail-order pharmacy) had higher PDCs (OR of 1.29) compared with those utilizing retail pharmacies, after controlling for days supply, OOP cost, various patient demographics, and PAB by multivariate logistic regression (Table 4). ${ }^{24}$ 


\begin{tabular}{|c|c|c|}
\hline \multirow{2}{*}{$\begin{array}{l}\text { TABLE } 4 \\
\text { Disease State }\end{array}$} & \multicolumn{2}{|c|}{$\begin{array}{l}\text { Odds of Patients Using Mail-Order } \\
\text { Pharmacies Being Adherent Compared } \\
\text { with Patients Using Retail Pharmacies }\end{array}$} \\
\hline & Group & Odds Ratio \\
\hline \multirow[t]{4}{*}{ Hypertension } & Iyengar et al. 201323,a & $1.11^{\mathrm{b}}$ \\
\hline & Iyengar et al. 201424,c & $1.29^{b}$ \\
\hline & Adams et al. $22, \mathrm{c}$ & $1.75^{\mathrm{b}}$ \\
\hline & Pittman et al. ${ }^{21, a}$ & $2.24 \mathrm{~b}$ \\
\hline \multirow[t]{2}{*}{ Cholesterol } & Iyengar et al. 201323,a & $1.19^{\mathrm{b}}$ \\
\hline & Iyengar et al. 201424,c & $1.26^{\mathrm{b}}$ \\
\hline \multirow[t]{7}{*}{ Diabetes } & Curkendall et al. $32, \mathrm{c}$ & $1.60^{\mathrm{b}}$ \\
\hline & Kirkman et al.33,a & $2.09 \mathrm{~b}$ \\
\hline & Iyengar et al. 201323,a & $1.15^{\mathrm{b}}$ \\
\hline & Iyengar et al. 201424,c & $1.25^{\mathrm{b}}$ \\
\hline & Gibson et al.28,c & \\
\hline & Oral medications only & $2.2^{\mathrm{b}}$ \\
\hline & With or without insulin & $2.3^{\mathrm{b}}$ \\
\hline \multicolumn{3}{|c|}{ 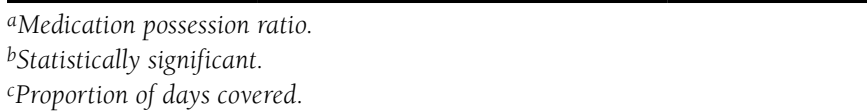 } \\
\hline
\end{tabular}

Conversely, the 2011 Khandelwal et al. study reported no statistically significant difference in medication adherence for patients using mail or retail pharmacies to fill 90-day prescriptions for antihypertensive agents. ${ }^{15}$

\section{Cholesterol/Hyperlipidemia}

In one of the first studies to describe differences in adherence between mail-order and retail pharmacies, White et al. (2002) calculated MPR for patients recently prescribed an HMG-CoA reductase inhibitor within a large managed care organization (MCO). After controlling for age, gender, and comorbidity by analysis of covariance, the authors found that patients receiving medications from mail-order pharmacies had 10.1 percentage points higher adherence than those using retail pharmacies (Table 3). ${ }^{25}$ White did not control for PAB, days supply, or patients' OOP costs.

Schmittdiel et al. (2011) reported that patients who used mail-order pharmacy in a large integrated health system versus the health system's local pharmacies had better low-density lipoprotein cholesterol (LDL-C) control. This study was completed in new users and controlled for differences between mail and retail patients using a difference-in-differences approach. ${ }^{26}$ In addition, Schmittdiel et al. used instrumental variable analysis, which, theoretically, controls for both observed differences (such as age and days supply) and unobserved differences (such as PAB) between retail and mail-order users. In this study, $10.8 \%$ more patients reached their target LDL-C levels in the mail-order group (Table 3).

Both Iyengar studies, which utilized MPR and PDC and reported ORs, reported better medication adherence in patients on hyperlipidemia medications utilizing mail-order rather than retail pharmacies (Table 3). ${ }^{23,24}$ In contrast, Khandelwal et al. reported no statistically significant difference in medication adherence for patients taking antihyperlipidemics across dispensing channels (Table 3). ${ }^{15}$

\section{Diabetes}

In 2010, Duru et al. examined patients with diabetes in a large integrated health system who were prescribed antiglycemic, antihypertensive, or lipid-lowering medications. The authors reported that those filling prescriptions through mail-order pharmacies, based on continuous measure of medication gaps $(\mathrm{CMG})$ and accounting for days supply and patient OOP costs by multivariate logistic regression, were $7.8 \%$ more adherent than those utilizing local pharmacies within the health system (Table 3). ${ }^{27}$ An instrumental variable analysis yielded similar results. This should have controlled for confounding variables, such as PAB, that were not measured in the study.

Gibson et al. (2010) examined the relationship between costsharing and adherence, as measured by PDC, to antidiabetic medications in commercially insured patients with type 2 diabetes. ${ }^{28}$ Mail-order usage was included as a control variable. The results indicated that any usage of mail-order pharmacies in the past year increased the odds of being adherent. The ORs were 2.2 for patients on oral antidiabetic medications and 2.3 for those on oral diabetic medications and/or insulin (Table 4). The analysis controlled for patient OOP costs but not for PAB or days supply.

Devine et al. (2010) found that patients aged under 65 years who switched from retail to mail-order pharmacy had 21.4 percentage point greater MPRs than patients who stayed with retail pharmacies (Table 3). ${ }^{29}$ The authors calculated MPR for patients matched by propensity score to account for confounding factors such as disease severity. They controlled for PAB by comparing pre- to postchanges in adherence. However, they did not account for patients' OOP costs or days supply, the latter of which they acknowledged may lead to higher adherence. ${ }^{29}$

Zhang et al. (2011) used claims data for Medicare Part D beneficiaries with diabetes to measure PDC. After propensity score matching on age, gender, disease severity, type of health plan, number of distinct medications, and duration of oral antidiabetic treatment in the prestudy period, they found that although antidiabetic medication adherence was low in both mail-order and retail pharmacies, patients who filled prescriptions at mail-order pharmacies had 7\% higher adherence than those who filled at retail pharmacies (Table 3). ${ }^{30}$ Zhang et al. did not control for days supply, patients' OOP costs, or PAB.

Khandelwal et al. (2011) reported a statistically significant difference in medication adherence for patients taking antidiabetics, where patients using the mail-order channel had higher adherence by 2.9 percentage points (Table 3). ${ }^{15}$ Of note, this study examined a number of therapeutic drug classes, and the antidiabetic drug class was the only one to have higher adherence in the mail-order group. 
Sharma et al. (2012) measured PDC in a population of privately insured patients taking antidiabetic medications, including insulin. The authors used linear regression to control for patient demographics including age, gender, and race, as well as copays, education, and median household income. The analysis did not control for days supply or PAB. The authors reported that patients using mail-order had higher adherence by 8.6 percentage points (Table 3$)^{31}$

Curkendall et al. (2013) measured PDC in commercially insured or Medicare patients taking noninsulin antidiabetics while accounting for patient factors including age, OOP costs, and region using a multivariate logistic regression. They did not control for days supply or PAB. Patients were assigned to adherent versus nonadherent cohorts based on $\mathrm{PDC} \geq 0.8$. Results indicated that "patients [who] fill their prescriptions by mail-order were 60 percent more likely to be adherent than those who did not" (Table 4). ${ }^{32}$

Kirkman et al. (2015) similarly assigned patients to adherent or nonadherent cohorts in a 2015 study. Adherence was determined by MPR for patients taking antidiabetics and enrolled in an MCO. The analysis controlled for age, gender, geographic region, OOP costs, disease burden, income, and education but not days supply or PAB using multivariate regression analysis. This study determined that patients who used mail-order pharmacies had higher adherence $\left(\mathrm{OR}=2.09\right.$; Table 4). ${ }^{33}$ Both Iyengar studies also examined patients with diabetes and found that patients using mail-order had higher adherence (Table 4). ${ }^{23,24}$

\section{Other Diseases}

In addition to the disease states described above, Khandelwal et al. found no statistically significant differences in adherence between mail-order and retail pharmacies in patients using antidepressants, beta blockers, or thyroid agents. ${ }^{15}$ Khandelwal et al. also combined data for all disease states and determined that, overall, patients who use mail-order pharmacies have a statistically significant $1 \%$ higher MPR value of $77.0 \%$ as opposed to $76 \%$ for retail pharmacies with 90 -day supplies.

\section{Discussion}

The existing research indicates that patients who use mail-order pharmacies have higher adherence than those using retail pharmacies. Of the 15 studies we examined, 14 found higher adherence at mail pharmacies, while the remaining study found equal adherence between channels. Further, most studies found substantial adherence differences between mail and retail pharmacies. The smallest statistically significant differences were an OR of $1.11,11,23$ a 3 percentage point difference in number of adherent patients (MPR or PDC >0.80), ${ }^{23}$ and an MPR difference of 7.0 percentage points. ${ }^{30}$ The largest differences were an OR of $2.3,{ }^{3,28}$ a 12.0 percentage point difference in number of adherent patients, ${ }^{20}$ and an MPR difference of 22.7 percentage points. ${ }^{20}$
The research does not provide as conclusive an explanation for why mail-order patients have higher adherence. The difference may be due to some inherent advantage of mail-order pharmacies such as greater convenience or privacy or it may be due to confounding factors that are related to both use of mail-order and adherence. It is as important to know why mail-order has an adherence advantage as to know that it does. If usage of mail-order pharmacies leads to better adherence because of some factor unique to this channel, then health plans and Medicare policy should support efforts to encourage patients to use mail-order. However, if mail-order pharmacies are associated with higher adherence because of confounding factors, such as days supply, then efforts should be directed at equalizing these factors between the channels.

Three factors have been frequently suggested as confounders: days supply, PAB, and lower mail-order copays. Patients who get 90-day supplies rather than 30-day supplies, those who were more adherent in the prestudy period, and those who have lower copays have been shown to be more adherent. $23,24,28,33,34$ Iyengar's 2 studies document the importance of PAB. ${ }^{23,24}$ In these studies, the ORs associated with PAB and adherence ranged from 4.5 to 9.5 across 3 drug classes. These ORs were much higher than those of any other factor in the model. By comparison, the ORs for mail versus retail dispensing channel ranged from 1.11 to 1.29. Most of the studies we reviewed did not control for these confounders. In fact, many attributed mail-order's adherence advantage to greater days supply or lower patient cost-sharing.

Four studies controlled for all 3 confounders. ${ }^{23,24,26,27}$ All 4 found higher adherence in mail-order pharmacy users. However, the magnitude of the differences between mail and retail pharmacy users was smaller. ORs in these studies ranged from $1.11^{23}$ to $1.29^{24}$ versus $1.60^{32}$ to $2.09^{33}$ in the studies not controlling for PAB, OOP, and days supply. Differences in percentages of adherent patients ranged from $3.2^{23}$ to $10.8^{34}$ in the studies that controlled for these confounders compared with $6.9^{30}$ to $12.0^{20}$ in the studies that did not. This indicates that part of the difference in adherence between channels may be due to mail-order pharmacies attracting patients who are more likely to be adherent, providing greater days supply, and having lower copays.

There are other reasons to question the conclusion that mail-order pharmacies have an inherent adherence advantage over retail pharmacies. Studies varied considerably in how they defined use of a mail-order pharmacy. At one extreme, Khandelwal and White studies required that patients get all study medications from a mail-order pharmacy to be considered mail-order users. ${ }^{15,25}$ At the other extreme, Schmittdiel required only that patients use mail-order at least once during the study period. ${ }^{34}$ The article does not indicate how many patients used mail-order pharmacies exclusively and how many used mail-order only once or twice. 
If there were an inherent characteristic of mail-order pharmacies that led to greater adherence, we would expect that greater use of mail-order pharmacies would be associated with higher adherence. Iyengar's studies provide the best test of this hypothesis. These studies divided patients into 3 groups: those using mail for $66.7 \%$ or more of their study prescriptions were classified as mail-order users, those using retail for $66.7 \%$ or more of their medications were classified as retail users, and those not in either of those categories were classified as mixedchannel users. ${ }^{23,24}$ If mail had an inherent advantage, then mail users should have greater adherence than mixed-channel users who, in turn, should have greater adherence than retail users. In fact, Iyengar's studies indicated that mail-order users had greater adherence than retail users but that retail users had greater adherence than mixed-channel users.

In most studies, there were large differences in baseline characteristics between the mail and retail populations. As shown in Table 2, patients in the mail-order samples had substantially higher PAB and lower numbers with Medicare lowincome subsidy, were more likely to receive financial incentives to use mail-order pharmacies, and had lower disease burden. All of these are confounding factors that would result in higher adherence in the mail-order group.

While most studies attempted to statistically control for differences between their retail and mail samples, it is useful to consider Schmittdiel's comment that "observational studies... cannot entirely control for differences between patients who utilize mail-order pharmacy services and those that do not."26

Two of the 4 studies that controlled for PAB, OOP, and days supply were conducted in the Kaiser Permanente integrated health care system. ${ }^{27,34}$ Patients in this system must use either Kaiser mail-order pharmacies or Kaiser outpatient pharmacies. The latter are located in Kaiser clinics. It seems likely that there are fewer Kaiser outpatient pharmacies than retail pharmacies that are located conveniently to Kaiser members. This may provide Kaiser members with an incentive to use mail-order pharmacies that would not exist for patients with access to traditional retail pharmacies.

The sponsorship and authors' employment for most of the studies raises the question of potential bias. Of the 15 articles reviewed, 1 was sponsored by a retail pharmacy chain; 9 were sponsored by or authored by employees of PBMs with a mail-order pharmacy; 3 were conducted in an integrated delivery system that owned a mail-order pharmacy; and 1 each was funded by the American Diabetes Association, a pharmaceutical company, and the Centers for Disease Control and Prevention. In reviewing the studies, however, the authors found no instances of bias.

\section{Limitations}

The vast majority of studies we reviewed used claims data to measure adherence and measured adherence as PDC, MPR, or CMG. These measures account for the days in which the patient had a "pill in hand" but do not necessarily reflect a "pill taken." As a result, they may overestimate adherence. However, this may have had minimal impact on the results of this review because the overestimation would have applied to both mail and retail pharmacies in the reviewed studies.

Of the 15 studies in this review, 2 specifically stated that they excluded auto-refill prescriptions, ${ }^{24,34}$ and 1 stated in a response to a letter to the editor that auto-refill prescriptions were not available at the time of the study. ${ }^{11,27}$ Of the remaining studies, 2 stated that they did not know how many of the prescriptions in their sample were auto-refills ${ }^{14,35}$ and the rest made no mention of auto-refill. As discussed earlier, auto-refill prescriptions may artificially inflate adherence estimates based on claims data. The effect of this limitation on the results of the review and on the individual studies depends on the extent to which one channel has a higher proportion of auto-refill prescriptions than the other. Because both mail and retail pharmacies offer auto-refill programs, and because the proportion of patients who select these programs probably varies from plan to plan, it is not possible to predict which channel would have more auto-refill prescriptions.

The definition of mail-order usage varied widely across studies, there were major differences in the baseline attributes of mail and retail users, and most studies did not control for potential confounders. This made comparing results across studies difficult.

All but 1 of the studies measured adherence as either PDC MPR, or CMG. The descriptions of how these measures were calculated in the published articles do not make it clear how the measures differ. Articles basically described both PDC and MPR as number of days for which medication was available in a time period divided by the number of days in the period. CMG differed only in that it was the proportion of days medication was not available. That is, CMG was essentially defined as $100 \%-P D C \%$.

Two studies measured adherence to asthma medications that did or may have included inhalers. ${ }^{14,35}$ Claims data-based measures of adherence to inhalers may be less accurate than measures of adherence to tablets and capsules because many patients do not use inhalers correctly. This can cause patients to stop using their inhalers because they feel they are not working or to overuse inhalers to make up for the fact that they are not getting symptom relief.

This review may be subject to publication bias. The studies that were sponsored by organizations that could be perceived to have an obvious bias (e.g., retail chains, PBMs and integrated health delivery systems that owned mail-order pharmacies) reported results that supported the sponsors' interests. This 
suggests that studies that did not support the sponsors' interests may not have been published. Further, this review only considered peer-reviewed journal articles. It did not include posters, published abstracts, or commercial reports. This probably increased the quality of the literature reviewed, but decreased the scope of the research evaluated.

\section{Conclusions}

The existing research provides strong evidence that patients who use mail-order pharmacies are more adherent than those who use retail pharmacies. At least part of the reason for the difference appears to be selection bias. Study patients who used mail-order pharmacies tended to have higher socioeconomic status and days supply of medicines received. In addition, in most cases, patients were offered financial incentives to use mail-order pharmacies, and, in the 2 studies that measured it, patients in the mail-order group had substantially higher PAB. ${ }^{23,24}$ Several studies attributed the mail-order adherence advantage to one or more of these factors. However, not all of the mail-order advantage appeared to be due to these factors: the few studies that statistically controlled for differences in these factors also found that patients using mail-order pharmacies were more adherent, although the differences between mail and retail users were smaller. $23,24,26,27$

The extent to which these results indicate an inherent adherence advantage of mail-order pharmacies (as distinct from adherence benefits due to greater days supply, lower copays, or more adherent patients selecting mail-order pharmacies) depends on how well the statistical controls adjusted for the differences between the mail and retail samples. These differences, differing definitions of mail-order usage, and the fact that patients with substantial use of both retail and mail-order settings had lower adherence than those using primarily retail pharmacies provide some reasons to doubt that mail-order pharmacy offers an inherent adherence advantage. While the current research indicates that use of mail-order pharmacies is associated with higher adherence, more research is needed before it can be conclusively determined that use of mail pharmacies causes higher adherence.

\section{Authors}

ELENA V. FERNANDEZ, BS, Virginia Commonwealth University School of Pharmacy, Richmond, Virginia; JENNIFER A. MCDANIEL, MSLS, Tompkins-McCaw Library for the Health Sciences, Virginia Commonwealth University, Richmond, Virginia; and NORMAN V. CARROLL, PhD, Department of Pharmacotherapy and Outcomes Sciences, Virginia Commonwealth University School of Pharmacy, Richmond, Virginia.

AUTHOR CORRESPONDENCE: Norman V. Carroll, PhD, Department of Pharmacotherapy and Outcomes Sciences, Virginia Commonwealth University School of Pharmacy, Box 980533, Richmond, VA 23298-0533. E-mail: nvcarroll@vcu.edu.

\section{DISCLOSURES}

No outside funding supported this study. Fernandez was partially funded by a Virginia Commonwealth University School of Pharmacy PharmD/PhD Summer Fellowship for work on this project. The authors declare no other potential conflicts of interest.

Study concept and design were contributed by Carroll and Fernandez. Fernandez took the lead in data collection, along with Carroll and McDaniel, and data interpretation was performed by Carroll and Fernandez. The manuscript was written and revised by Carroll and Fernandez, with assistance from McDaniel

\section{REFERENCES}

1. Osterberg L, Blaschke T. Adherence to medication. N Engl J Med. 2005;353(5):487-97. Available at: http://www.nejm.org/doi/full/10.1056/ NEJMra050100. Accessed September 19, 2016.

2. New England Healthcare Institute. Thinking outside the pillbox: a system-wide approach to improving patient medication adherencne for chronic disease. NEHI Research Brief. August 2009. Available at: http://www. nehi.net/writable/publication_files/file/pa_issue_brief_final.pdf. Accessed September 19, 2016

3. Naderi SH, Bestwick JP WD. Adherence to drugs that prevent cardiovascular disease: meta-analysis on 376,162 patients. Am J Med. 2012:125(9):882-87.el. Available at: http://www.sciencedirect.com/science/ article/pii/S0002934312000186. Accessed September 19, 2016.

4. Nieuwlaat R, Wilczynski N, Navarro T, et al. Interventions for enhancing medication adherence. Cochrane Database Syst Rev. 2014;(11):CD000011. Availble at: http://onlinelibrary.wiley.com/doi/10.1002/14651858.CD000011. pub4/abstract;jsessionid=3AC02ED1B3CD5173363E2A268F127760.f03t01. Accessed September 19, 2016.

5. Donnan PT, MacDonald TM, Morris AD. Adherence to prescribed oral hypoglycaemic medication in a population of patients with type 2 diabetes: a retrospective cohort study. Diabet Med. 2002;19(4):279-84

6. Bramley TJ, Gerbino PP, Nightengale BS, Frech-Tamas F. Relationship of blood pressure control to adherence with antihypertensive monotherapy in 13 managed care organizations. J Manag Care Pharm. 2006;12(3):239-45. Available at: http://www.jmcp.org/doi/10.18553/jmcp.2006.12.3.239.

7. Jackevicius CA, Mamdani M, Tu J V. Adherence with statin therapy in elderly patients with and without acute coronary syndromes. JAMA. 288(4):462-67. Available at: http://jama.jamanetwork.com/article. aspx?articleid=195144. Accessed September 19, 2016

8. Conn VS, Ruppar TM, Enriquez M, Cooper P. Medication adherence interventions that target subjects with adherence problems: systematic review and meta-analysis. Res Soc Adm Pharm. 2016;12(2):218-46. Available at: http://www.sciencedirect.com/science/article/pii/S1551741115001187. Accessed September 19, 2016.

9. Skinner JS, Poe B, Hopper R, Boyer A, Wilkins CH. Assessing the effectiveness of pharmacist-directed medication therapy management in improving diabetes outcomes in patients with poorly controlled diabetes. Diabetes Educ. 2015;41(4):459-65. Available at: https://www.ncbi.nlm.nih.gov/pmc/ articles/PMC4504766/. Accessed September 19, 2016.

10. Choudhry N, Fischer M, Smith B, et al. Five features of value-based insurance design plans were associated with higher rates of medication adherence. Health Aff (Millwood). 2014;33(3):493-501.

11. Brown T, Rickles NM, Nathaniel MR. Mail-order versus local pharmacies on adherence: study methods make for unfair comparison. Am J Manag Care. 2010;16(3):226-27; author reply 227-28.

12. Liberman JN, Girdish C. Recent trends in the dispensing of 90-daysupply prescriptions at retail pharmacies: implications for improved convenience and access. Am Health Drug Benefits. 2011;4(2):95-100. Available at: https://www.ncbi.nlm.nih.gov/pmc/articles/PMC4106580/. Accessed September 19, 2016. 
13. Carroll N V, Brusilovsky I, York B, Oscar R. Comparison of costs of community and mail service pharmacy. J Am Pharm Assoc (2003). 2005;45(3):336-43

14. Visaria J, Seoane-Vazquez E, Szeinbach SL, Rodriguez-Monguio R. Comparing the cost of community pharmacy and mail-order pharmacy in a U.S. retirement system. Int J Health Plann Manage. 2012;27(1):e41-e50.

15. Khandelwal N, Duncan I, Rubinstein E, et al. Medication adherence for 90-day quantities of medication dispensed through retail and mail order pharmacies. Am J Manag Care. 2011;17(11):e427-e34.

16. Brennan TA, Dollear JT, Hu M, et al. An integrated pharmacy-based program improved medication prescription and adherence rates in diabetes patients. Health Aff (Millwood). 2012;31(1):120-29. Available at: http://content. healthaffairs.org/content/31/1/120.long. Accessed September 19, 2016.

17. Ratanawongsa N, Karter AJ, Parker MM, et al. Communication and medication refill adherence: the Diabetes Study of Northern California. JAMA Intern Med. 2013;173(3):210-18. Available at: https://www.ncbi.nlm.nih.gov/ pmc/articles/PMC3609434/. Accessed September 19, 2016.

18. Bauer AM, Schillinger D, Parker MM, et al. Health literacy and antidepressant medication adherence among adults with diabetes: the diabetes study of Northern California (DISTANCE). J Gen Intern Med. 2013;28(9):1181-187. Available at: http://link.springer.com/article/10.1007\% 2Fs11606-013-2402-8. Accessed September 19, 2016.

19. Liberati A, Altman DG, Tetzlaff J, et al. The PRISMA statement for reporting systematic reviews and meta-analyses of studies that evaluate health care interventions: explanation and elaboration. J Clin Epidemiol. 2009;62(10):el-e34. Available at: http://www.sciencedirect.com/science/ article/pii/S0895435609001802. Accessed September 19, 2016.

20. Visaria J, Frazee SG DS. Asthma controller adherence in mail order pharmacy compared to retail pharmacy. Am J Pharm Benefits. 2012;4(3):e73-e380. Available at: http://www.ajmc.com/journals/issue/2012/ajpb_mayjun2012/ asthma-controller-adherence-in-mail-order-pharmacy-compared-to-retailpharmacy. Accessed September 22, 2016

21. Pittman DG, Tao Z, Chen W, Stettin GD. Antihypertensive medication adherence and subsequent healthcare utilization and costs. Am J Manag Care. 2010;16(8):568-76. Available at: http://www.ajmc.com/journals/ issue/2010/2010-08-voll6-n08/AJMC_10aug_Pittman_568to576/. Accessed September 19, 2016.

22. Adams AS, Uratsu C, Dyer W, et al. Health system factors and antihypertensive adherence in a racially and ethnically diverse cohort of new users. JAMA Intern Med. 2013;173(1):54-61. Available at: http://archinte.jamanetwork.com/article. aspx?articleid=1485080. Accessed September 19, 2016

23. Iyengar R, Henderson R, Visaria J, Glave Frazee S. Dispensing channel and medication adherence: evidence across 3 therapy classes. Am J Manag Care. 2013;19(10):798-804. Available at: http://www.ajmc.com/journals/ issue/2013/2013-1-vol19-n10/Dispensing-Channel-and-Medication-AdherenceEvidence-Across-3-Therapy-Classes/. Accessed September 19, 2016.

24. Iyengar RN, Balagere DS, Henderson RR, LeFrancois AL, Rabbitt RM, Frazee SG. Association between dispensing channel and medication adherence among Medicare beneficiaries taking medications to treat diabetes, high blood pressure, or high blood cholesterol. J Manag Care Spec Pharm. 2014;20(8):851-61. Available at: http://www.jmcp.org/doi/10.18553/ jmcp.2014.20.8.851.
25. White TJ, Chang E, Leslie S, Gilderman A, Berenbeim DM, Dezii CM MC. Patient adherence with HMG reductase inhibitor therapy among users of two types of prescription services. J Manag Care Pharm. 2002;8(3):186-91. Available at: http://www.jmcp.org/doi/abs/10.18553/jmcp.2002.8.3.186.

26. Schmittdiel JA, Karter AJ, Dyer W, et al. The comparative effectiveness of mail order pharmacy use vs. local pharmacy use on LDL-C control in new statin users. J Gen Intern Med. 2011;26(12):1396-1402. Available at: http://link.springer.com/article/10.1007\%2Fs11606-011-1805-7. Accessed September 19, 2016.

27. Duru OK, Schmittdiel JA, Dyer WT, et al. Mail-order pharmacy use and adherence to diabetes-related medications. Am J Manag Care. 2010;16(1):33-40. Available at: http://www.pubmedcentral.nih.gov/articlerender.fcgi?artid=3015 238\&tool=pmcentrez\&rendertype=abstract. Accessed September 19, 2016.

28. Gibson TB, Song X, Alemayehu B, et al. Cost sharing, adherence, and health outcomes in patients with diabetes. Am J Manag Care. 2010;16(8):589600. Available at: http://www.ajmc.com/journals/issue/2010/2010-08-voll6n08/AJMC_10aug_Gibson_589to600/. Accessed September 19, 2016.

29. Devine S, Vlahiotis A, Sundar H. A comparison of diabetes medication adherence and healthcare costs in patients using mail order pharmacy and retail pharmacy. J Med Econ. 2010;13(2):203-11. Available at: http://www. tandfonline.com/doi/abs/10.3111/13696991003741801?journalCode=ijme20. Accessed September 19, 2016.

30. Zhang L, Zakharyan A, Stockl KM, Harada ASM, Curtis BS, Solow BK. Mail-order pharmacy use and medication adherence among Medicare Part D beneficiaries with diabetes. J Med Econ. 2011;14(5):562-67. Available at: http://www.tandfonline.com/doi/abs/10.3111/13696998.2011.598200?journ alCode=ijme20. Accessed September 19, 2016.

31. Sharma KP, Taylor TN. Pharmacy effect on adherence to antidiabetic medications. Med Care. 2012;50(8):685-91.

32. Curkendall SM, Thomas N, Bell KF, Juneau PL, Weiss AJ. Predictors of medication adherence in patients with type 2 diabetes mellitus. Curr Med Res Opin. 2013;29(10):1275-86. Available at: http://www.tandfonline.com/ doi/abs/10.1185/03007995.2013.821056?journalCode=icmo20. Accessed September 19, 2016.

33. Kirkman M, Rowan-Martin M, Levin R, et al. Determinants of adherence to diabetes medications: findings from a large pharmacy claims database. Diabetes Care. 2015;38(4):604-09. Available at: http://care.diabetesjournals. org/content/38/4/604.long. Accessed September 19, 2016.

34. Schmittdiel J a., Karter AJ, Dyer WT, Chan J, Duru OKK. Safety and effectiveness of mail order pharmacy use in diabetes. Am J Manag Care. 2013;19(11):882-87. Available at: http://www.pubmedcentral.nih.gov/ articlerender.fcgi?artid $=4278640$ \&tool=pmcentre $z$ \&rendertype $=$ abstract . Accessed September 19, 2016.

35. Khandelwal N, Duncan I, Rubinstein E, Ahmed T, Pegus C. Community pharmacy and mail order cost and utilization for 90-day maintenance medication prescriptions. J Manag Care Pharm. 2012;18(3):247-55. Available at: http://www.jmcp.org/doi/10.18553/jmcp.2012.18.3.247. 